\title{
RECOGNITION, WORK, TREATMENT
}

\author{
Gabriele Profita
}

\section{QUERY SHEET}

This page lists questions we have about your paper. The numbers displayed at left can be found in the text of the paper for reference. In addition, please review your paper as a whole for correctness.

Q1. Au: Please confirm title appears correctly.

Q2. Au: Please confirm author name and affiliation appear correctly.

Q3. Au: Please confirm abstract appears correctly.

Q4. Au: Please confirm keywords appear correctly.

Q5. Au: Please confirm level headings appear correctly throughout.

Q6. Au: Please confirm contact information appears correctly.

Q7. Au: Is there a page number for Foucault? You say "so far unpublished" but it is listed in the references with two different years.

Q8. Au: Deferred to a spatial and temporal what? Please clafify (" Today's supremacy originating from the fetish of ...").

Q9. Au: Whose term is "misfortune of horizontality"? Please add citation if needed.

Q10. Au: Should Kaës 2012 in text but updated to " 2013 " for as per the reference and the Note?

Q11. Au: Could you please provide page numbers for Ricoeur quotes?

Q12. Au: Please add Taylor 1994 to the references.

Q13. Au: Habermas \& Taylor is $1996 / 2002$ in the reference; what is the page number for the quote?

Q14. Au: What is the source material for Taylor ("Taylor always specifies ...")?

Q15. Au: Please revise the sentence "When psychology aspires ..." for clarity if possible/appropriate.

Q16. Au: Are the angular brackets used in Honneth or are you indicating text you inserted? If the latter, use square brackets [].

Q17. Au: Could you please provide a page number for Honneth quote? 
Q18. Au: Please add Ehremberg 2012 and Honneth 1998 to the references; please provide attribution (Name, year) and a page number for the quote ("mythological valorization of autonomy").

Q19. Au: Please add the year and page number for Ehremberg ("are addressed to as moral consciences").

Q20. Au: Please add the year and page number for Ehremberg ("inter-subjective negotiation").

Q21. Au: Please add Hirigoyen to the references and a year to the text.

Q22. Au: Could "so as it is the answer they give": be revised for clarity, or should it remain as is?

Q23. Au: Could you please provide page number(s) for Migone 2013 quote?

Q24. Au: Please add Weber to the references and a year to the text.

Q25. Au: Could "limits first of all connected to ethical responsibility?" be revised for clarity, or should it remain as is?

Q26. Au: Could you please provide page number for the Dubet quote ("the denominator of a large ...")?

Q27. Au: Could you please provide a page number for the Dubet quote ("When individuals try to ...")?

Q28. Au: Could you please provide a page number for the Honneth quote ("preliminary recognition")?

Q29. Au: Judge, Tibaldi: do you mean Judge \& Tibaldi? There is no listing for this callout in the references.

Q30. Au: Please provide attribution (author, year, p. \#) for the quote "crystallization ..."

Q31. Au: What authors are you referring to here ("In this case - the authors ...")? Honneth and Hartmann? Please provide attribution (author, year, p. \#).

Q32. Au: Could you please provide a page number for Ehremberg ("the trouble of being ourselves")?

Q33. Au: Could you please provide a page number for Ehremberg quote ("We are now living in an individualism characterized ...")?.

Q34. Au: Please provide publisher location missing for Vaccaro.

Q35. Au: In which Honneth reference is Amerio cited?

Q36. Au: It is unclear what is meant by Weber (Typed) ; if you mean personal communication, please provide the month day, year.

Q37. Au: Please provide the original publication date correct for Arendt?

Q38. Au: Dubet : Please translate cit. into English.

Q39. Au: Foucault: unclear what type of reference this is. Please consult APA Handbook Sixth Edition for chapters in books or the appropriate reference example for this instance; is the Original work date correct?

Q40. Au: Is the original publication date correct for Habermas \& Taylor?

Q41. Au: Could you please provide chapter page numbers for Honneth \& Hartmann?

Q42. Au: Lavie: Is there a vol. number available? Please provide the article's page range. 
Q43. Au: Is the original work year correct for Mauss? Is this a book chapter? If so, please consult APA Handbook Sixth Edition for the correct style/elements. If it is not a book chapter, please consult the Handbook for the correct style.

Q44. Au: Is Migone an article or book chapter? You have elements of both. Please consult the APA Handbook Sixth Edition.

Q45. Au: If possible, please provide English translations for all of the titles in the reference list.

\section{TABLE OF CONTENTS LISTING}

The table of contents for the journal will list your paper exactly as it appears below:

Recognition, work, treatment

Gabriele Profita 


\author{
Gabriele Profita \\ University of Palermo, Palermo, Italy
}

The article I am going to propose is a reflection on the theme of recognition in working and social contexts, and focuses on problems and troubles people cope with in this historical moment. This is a period during which reciprocity and recognition relationships involving our education and work career seem to have no more value, because the world of work now focuses on involving people in production and does not care about involved subjects' life plans. I also wish to point out risks and sufferance affecting subjects who perceive with always greater precision that they are more and more often oppressed by labor and mind exploitation, rather than considered human resources with a working competence who can participate in a wider project.

KEYWORDS: Identity, inter-subjectivity, recognition, work

\title{
INTRODUCTION
}

The themes of recognition and, consequently, reification are now extremely hot topics due to a consolidation in consciences of the ideals pertaining to economic and financial neoliberalism, which has also imposed itself as life model. If during the Middle Ages the center of human existence was spinning around the theme of salvation and obedience to God's Law, in the same way money, market, and finance have taken on the role of unquestionable value, and, at the same time, threatening Moloch. What is more, the bewilderment connected to the crisis of institutions, incapable to mediate and regulate the economic-financial army, the following loss of ethical orientation, the impossibility to find a commonly shared series of values,

25 has given birth, among the various problems, to that very common feeling (not) to see or feel oneself as recognized, be forced in an always tighter habitus, in a regime where freedom is mainly developed in production and consumption.

\section{THE SOCIETY OF INDIVIDUALS: LIMITS AND POSSIBILITIES}

The society of individuals, which has released us from many encumbrances and constrictions typical of traditional communities, has left at the same time a lack of indications and reference points, which appear as uncertain and temporary. If at the end of the Second World War it had been possible to limit inequalities and increase

Address correspondence to Gabriele Profita, University of Palermo, Psychology Department, Viale delle scienze, Bldg. 15, Palermo, Italy.E-mail: gabriele.profita@unipa.it 
the standard of freedom, during the last decades, what seemed to have become true in democracy has been dangerously and urgently decreasing. A greater lack of clarity and a common feeling of helplessness concerning geopolitics have consistently limited the single people's ability to affect general as well as their own reality. As a consequence, even the people who can enjoy deeply interiorized certainties, strong acquisitions fulfilled during their lifetime, experience a very difficult path, sprinkled with unexpected and sudden changes that require contortions and metamorphoses hard to understand and manage. Human and social disciplines, born from the need of a cognitive and emotional help with respect to the disorder caused by the industrial world, are also experiencing the same kind of crisis, the end of which is still far away, and are involved in a sociopolitical irrelevance making them helpless and outdated. The "scientific and rational mindset" is celebrated everywhere, being the only one that allows development and profit, while reflexive thinking is considered as a mere waste of time.

Concrete everyday reality is actually organized around a scientific and productive, rational and inevitable power by definition.

In a conversation of 1978 with Colin Gordon and Paul Patton, so far unpublished, Michel Foucault sketches the strength contained in the rationality principle: "The genesis of rationality just consists of the genesis of a reason exercising supremacy" (Foucault, 1978/2014). Today's supremacy originating from the fetish of productive rationality, a self-regulating market, the commonly shared project of an expansive well-being hide in all cases a cost of sufferance inflicted to the majority of the world's inhabitants, redeemable only in a future vaguely indicated as favorable and common to all, but always deferred to a spatial and temporal. Elsewhere. In reality it concretely becomes true only for very few people.

We are therefore celebrating now the "misfortune of horizontality"; that is, the loss of forms ensuring a stable reference, but also a downward standardization, where for the majority of people the promised financial means are shrinking in the wake of a propagandized, but hardly achievable, opulence. As Ehremberg (2010) had explained, ${ }^{1}$ the decline of the Institution and the crisis of the symbolic makes taking on a wider and more perspective viewpoint difficult, sometimes even impossible. There is no support on behalf of the communities, our beloved ones' concrete solidarity that, in critical times, always becomes a concrete chance to overcome material and spiritual troubles. Everyone's loneliness finds no handhold, no strength that can support it, and so the solidarity among human beings seems to disappear, replaced by a competitive regime.

We may be at the peak of the incapable man's phenomenology, to negatively mention Ricoeur (2005), concerning a human being who cannot suitably speak, act, or talk about things or himself in the multiplicity of the communicative noise. The reflexive ability that is always associated with the discussion with otherness, the dynamics between interlocutors, suffers, this way, a setback for which it is hard to undertake and maintain forms of practicable relationship with confidence. We are probably not really facing the individual's control over the world, but rather his subjection to the logics that stifle him. A subject Ricoeur considers as looking for a hermeneutics of himself and the world, constantly working the meaning of himself out, needs the other and many others. In this way both the recognition of oneself 
80 and the mutual recognition, where the "gift" represents its higher form, are crucial themes to escape reified and alienated subjectivity forms (Mauss, 1950/2000).

Children ask their parents, teachers, reference figures, to "be seen," considered seriously, in other words, recognized. ${ }^{2}$ On the contrary, not being seen or being neglected will cause the child an incredible anguish, which, if prolonged, can also

85 provoke serious psychic problems. This wish and "attitude" to recognition will no more be lost, and show in every relational moment of their future life, because it is at the origin of the certainty to exist, be alive, and participating to the world.

Kaës, too, considers "malêtre" (2012), ${ }^{3}$ as the reduction of all relationship possibilities, annihilated by hypermodernity, the breakup of all rules, unless the one

90 leading to a tangible and immediate profit where references to human shrink.

It would be along the way that it sketches the crisis of contemporary human beings and the sciences showing interest in them, through philosophers, sociologists, psychoanalysts, and psychologists. The analysis of contemporary problems and discomforts is wide and detailed. As far as recognition is concerned, at least

95 in Italy, there is still a rhapsodic reflection and lack of attention. Except for some very restricted cultural domains, the theme seems not very present in researchers' reflections. ${ }^{4}$ Maybe because dealing with it highlights its intrinsic relational nature and stimulates the direct commitment in order to promote real recognition actions.

\section{ABOUT RECOGNITION, WORK, AND TREATMENT}

100 The term "recognition" presents various ambiguities and meanings, which are worth being pointed out.

As far as the width of the concepts the term conveys are concerned, after a thorough and complex examination, Ricoeur finally states that it contains at least these meanings:

105 1. "Grasping (an object) with our mind, our thought, connecting images and perceptions about it between each other; making distinctions, identifying, being familiar with it through our memory, judgment, action. [ ...]

2. "Accepting, considering as true (or thinking it is). [ ...]

3. "Showing with our gratitude we are in somebody's debt (for something, an action)" (Ricoeur, 2005).

If the meanings the term has in the various languages (in French, for example, réconnaissance contains both recognition and gratitude) may be several, which gives the reason for the deeply cultural essence of its meanings, many are the places where the recognition action or the actors of this process can be visualized.

Not least, the wish for recognition seems to undergo a redefinition of its individuality, and changes according to the development and transformations of its identity.

From his viewpoint, Taylor $(1994,2009)$ defines present times as "the era of authenticity," which, after a long historical incubation moment, may be recog120 nized as a paradoxical union of loneliness and blending. Loneliness derives from individualist selfishness, blending several behaviors and individual choices that seem strictly connected with each other and inevitable, and deriving from mass 
media pressure. The most interesting characteristics here is that self-fulfillment, feeling committed to our own personal fulfillment, mostly as far as work is concerned, gets a moral connotation. Even if authenticity, so as the idea of dignity, appears as "a filiation of the decline of hierarchic society" (Taylor, in Habermas \&

Q13 Taylor, 2008), it however contains the moral incentive supporting it as a positivity element.

When we speak about moral incentive we refer to relationships, the possibility to discuss "according to reason about ideals and conformity of practical actions according to these ideals" (Taylor 1994, p. 30).

We are then called to propose the theme of morality in psychological disciplines, too, leaving aside for a moment the issue of a strictly naturalistic psychology, where the dimension of moral actions, the human ability to cope with structuralist alibis (we are inside a system or forced in a habitus), to take on really authentic reflexivity and positions.

Taylor always specifies two recognition kinds or requests concerning the respect of each individual's unique identity, and the respect of practices and ways to conceive the world. This latter includes minorities and the disadvantaged: Black people, women, marginalized natives such as American Indians, and so on. If in the first case recognition involves individual abilities and characteristics, in the second, social classes or ethnicities. The fight for recognition is mostly evident in the class struggle or the minorities' claims, and especially involves a struggle either for power or to free themselves from humiliating or exploitation conditions. The fight for recognition (Honneth, 2000) may then become a fight for emancipation and social redemption.

So far, recognition is seen as a social issue, involving a clash among various groups, minorities or majorities, looking for a way to free themselves, claim moral or juridical rights, and, by scale extension, a geopolitical issue. When psychology aspires to be a science of nature, it does not seem to be involved in it, the problem of recognition belongs to the domain of philosophy, morality, and political struggle Q15 for rights.

There is, however, a crucial aspect of psychology in its different spheres of action and competence, which concerns human emotions and feelings: feeling recognized, suffering for the lack of recognition, looking for a recognition of our abilities and value, being visible and appreciated, are today qualities each one of us highly considers, and for which one is ready to start quarrels and conflicts.

For clinical psychology and psychotherapy, for work and organizational psychology, recognition theory can thus provide for favorable indications concerning diagnosis, to understand discomfort and orient ourselves in the operational intervention provided that we revise the theme with respect to specific activities.

From a psychological viewpoint, the debate on the theme of recognition is, however, not very well-known, ${ }^{5}$ and mostly seen as a political or sociological theme concerning social groups or juridical issues, and particularly the discussions pertaining philosophy.

This theme, however, closely involves psychology: we are speaking, for example, of visibility, being or feeling seen, the look; as if all individual or social identities were a matter of visibility. 
Axel Honneth (2000, 2006, 2007, 2013), present director of the Frankfurt School, proposes a recognition theory where the idea of conscience or selfconscience, adopted by Hegel, connects with the concept of intersubjective autonomy. The subject is always determined in relation with the other and not autonomously. Each and every human experience deprived of other people's recognition is frustrating and painful. Besides Hegel, Honneth refers to empirical researches and the contribution of psychoanalysis, which considers it an important reference point for its critical theory. In The Struggle for Recognition (2000) human conflicts are considered and dealt with as a request for recognition. The dialectics between servant and master, recovered by Hegel, assume that the con-

180 science a subject has of himself is strictly connected to the other's conscience, thus determining a bond of reciprocal dependence among people.

\section{Honneth's Developmental Models}

Honneth finds three recognition development moments.

The first, characterized by the theme of love, is intrinsic to the relationship

185 mother-child and overcoming the ambiguity between dependence and autonomy. A "sufficiently good" mother, a term used by Winnicott, which Honneth widely draws on, allows the child's aggressive and destructive impulses, which originate from dependence and separation anxiety. When, and if, the child is reassured by his mother's stable and comfortable presence, he will then be able to manage his anxiety and start being progressively autonomous, since he has acquired an idea of stability about the world around him and, for this reason, a certain self-confidence. The progressive and not traumatic detachment from his mother thus becomes the paradigm both of the other person's recognition as autonomous subject, and, in a second evolutionary moment, the possibility to participate to social and political life. A recognition act is the visible manifestation of the individual's ability to decentralize from himself, and give the other "a moral authority on ourselves because of his value" (Honneth, 2006, p. 243).

In order to have a relationship on the juridical level (second model), a recognition based on reciprocal respect, which becomes the ground for social and political

200 life, is necessary. Regarding this, Honneth (2006) says: "We must have assimilated the normative perspective of <other people in general $>$, which leads us to recognize other community members as right bearers, in order to be able to consider ourselves juridical people at the same time, in so far as we are sure to see our needs fulfilled by the social framework" (p. 183).

205 The third recognition model finally finds its grounds in the collective ethical sphere, where the individual always needs to perceive himself as useful to the collectivity and, in this perspective, considerable. Engaging in the social construction and polis activities implies a recognition request which, in case it does not take place, could cause a struggle for recognition. The chance to start hostilities and conflicts is thus potentially ready, with its positive aspects of change, new balance, turnover, but also the risks it involves: violence, disorders, impasse in relationships, communications, and solutions of problems.

Social esteem is strictly connected to qualities and abilities individuals are able to express. 
In the complexity of modern social life, and particularly as far as work and social recognition of our activity are concerned, Honneth sees an important element to strengthen individual identities.

Summing up, recognition is developed at least on three different levels:

1. Preliminary self-recognition, through our mother; self-love.

2. Autonomy and generalized recognition of the other person, which is carried 220 out on an ethical and juridical level; self-respect.

3. Recognition of our skills (but also the limits we have or which are imposed to us); self-esteem.

\section{Reification}

As far as the theme of reification is concerned, Honneth (2007) thinks that it takes place not only depending on the situation of subjection to the market and the laws of liberal economics, but mostly because human beings "have lost track of their preliminary recognition" (p.), that is everything allows the autonomy and development of relational skills.

An extremely heart-felt theme thus unfolds, which connects the individual and his peculiar characteristics with work and social reality and the problem of contemporary man's sufferance is highlighted, as well as his difficulty to achieve his goals.

Q18 As for this, Ehremberg's criticisms (2012) to Honneth (1998) are pertinent and can be summarized in an individual "mythological valorization of autonomy."

Ehremberg's line of reasoning is developed starting from Honneth's conception of social life, according to which inter-subjective relationships "are addressed to as moral consciences" and not as tangible social relationships. They are not simply ethical relationships, consciences confronting each other in a neutral competition, but have a special social character that produces and implies constrictions partially escaping individual consciences and single people's chance of incidence. It is not just a problem concerning will, even though it has its importance, but it is necessary that an "inter-subjective negotiation" is activated. And in a social reality where there are inputs to cooperate, but mostly to compete, recognition acquires a special incidence. It places itself in the continuous negotiation of the other person's value, which cannot only be theoretically represented, but must be identified in a permanent practice.

This occurs mainly because the third function of mediation, control, and stability institutions has become blurry, because of their decay and loss of consistence, and shows today more on the level of bureaucratic constraint rather than support and regulation. Single individuals are maybe masters of their own fates, but in a quite undetermined and uncertain normative framework. Symptomatic reactions affecting individuals thus start pertaining to clinical psychology and psychopathology, are ascribed to the individuals' ability or inability to face them, with no available help or handhold on the part of supporting institutions: family, 255 work organization, an apparently distant, weak State withdrawn in a dull and unrecognizable background. 
Voluntary work initiatives and citizens' attempts to privately establish institutions mobilize and fill the gaps of traditional institutions, trying to occupy spaces 260 that would otherwise be left uncovered for their incompetence or inability. At the same time, insurance companies, meant as defense or safety systems, have occupied the place the State and its services have vacated, proposing a profit logic disguised as support.

Christophe Dejours gives prominence to contemporary man's pains as far as work is concerned in his Souffrance en France (2009), maintaining, among other things, that the lack of recognition is the first cause of pain and that, on the contrary, recognition represents a possible answer to the present condition of distress. This is what Dejours says: "The meaning of pain actually depends on recognition. When the quality of my work is recognized, my efforts, anxieties, doubts, disappointments, frustrations are, too, and they all acquire a meaning. Pain has not thus been useless but consequently made me a different subject than what I was before my recognition" (2009, p. 41).

\section{Dejours: About Pain at Work}

The main reasons guiding human actions, as well as the thought deriving from them, are structured around the theme of pain. After Dejours has presented his theory on the attempt carried out by the modern work organization to "trivialize" pain (Arendt, 1963/2003), by means of a combination of various causes, which range from indifference toward pain and suffering to the fortuity of destiny and absence of indignation, he points at the system and its articulation on different plans as responsible for suffering at work. Dejours's observations are disheartening for many reasons. At the origin of suffering in workplaces there is a combination of responsibilities, a collusion among the various actors that is hard to get out of. On one hand leaders who embrace the neoliberal doctrine and require grievous or paranoiac professional profiles, on the other collaborators who organize them-

285 selves on a defensive and colluding level with the first. Finally, the people who refrain and isolate from social active life, a sort of social oblivion that tends to forget rather than strongly participate.

The second edition of Dejours's book includes an afterword, where his and other authors' later research (i.e., Marie-France Hirigoyen with Le Harcèlement

290 moral) points out that the situation in France has become even worse. The phenomenon involves every industrialized country, which, with more or less accelerated times, has followed the same drift. Dejours particularly highlights two important factors in a work organization evolution: individualized assessment and total quality, which contribute to an organized control of work.

295 As far as the problem of total quality is concerned, it cannot be such unless it is an advertising slogan. The so-called total quality produces, on the contrary, the tendency to hide the true reality of events, highlighting virtues, but hiding their unlikelihood and virtual essence. Total quality does not exist unless as aspiration but which often generates dishonest behaviors and actions.

300 Effects of individualized assessment are not less harmful, especially on the level of relationships. Assessment causes fear and resentment in place of 
trust-based relationships. The climate of suspicion and the diffidence it generates cause a loss of conviviality, the disappearance of the sense of community, while the workplace is more and more perceived as unreliable and sick. Consequences are clear: a widespread loneliness, the reduction of the feeling to be able to act and concretely modify reality, the neat decrease of work quality. Dejours's conclusion is that, at the end of this individualized assessment process, what was hoped in terms of productivity will not be produced, but we will only see harmful side effects, for people and companies. In this case, too, an increase of recognition practices, of the value human resources have is proposed as an antidote to quantitative assessment, in order for them to be recognized and therefore improved.

\section{WORK AND TREATMENT}

In this framework, where work acquires a strong relevance and, at the same time, a remarkable oppressiveness, the single person's loneliness takes shape since he/she cannot often find other solutions unless a virtual interconnection that gives an illusory reassurance with respect to actualized relationships. On a clinical level, even in treatment relationships, it is inevitable to reconsider functions, goals, and methods. The majority of today's pains and pathologies can be referred to the relationship with work, the interconnection between private and public spaces, being overwhelmed by social urgencies that find no relief.

From an institutional viewpoint, social services as well as those dealing with psychology and psychotherapy are presently being dismantled. Treatment and support services are often supported by voluntary work or private people, who, in turn, since they are lacking their public support, in order to survive, deviate from the purposes they were created for.

At the same time, the request for help is also transforming. On one hand it has grown both in quantity and quality, showing new pathologies, on the other it is always more subject to the market, in financial terms and on the level of technical and theoretical answers, due to the fact that psychopathological and social are always more intertwining. Thus, psychotherapeutic techniques and specializations for age groups, disease types, cultural differences, gender, and so on, have been increasing during these years. Drawing a list of psychotherapeutic "specialties" means today entering a labyrinth where the same streets (and paths) always cross each other in an unrestrained and imprecise bustle, where it is difficult to distinguish (especially for users), but for specialists, too, if psychotherapeutic techniques are effective, if they either answer real criteria or are used to wheedle loneliness, or, even worse, are just the result of a confused impulse of the market, so as it is the answer they give.

Academic disciplines, too, appear more and more hybridized: there is a clinical psychology, but pedagogy and sociology, too, have been equipping themselves in this respect, becoming clinical pedagogies and sociologies, where the disciplinary boundary becomes uncertain and evanescent. "Traditional" disciplines (psychology, sociology, anthropology) are evolving according to a common habit that looks into interconnections, hybridizations, trespassing, for new spaces, or perhaps just a visibility. In particular, they move away from application practice to focus on 
basic research, with not always praiseworthy results, and subject to the requests of a controversial assessment criterion.

The interconnection between psychopathology and social discomfort is actually present in the new DSM-5, in that "scientific" attempts to classify psychic disturbances, where human existence, and sufferance concerning it, often seem to be classified under the form of pathology. Migone (2013) thinks that in the new Manual, the boundary between normality and pathology is even more uncertain, and the detection method adopted to define diagnostic criteria shows as quite far from being meticulous and scientific, getting to the conclusion that: "We can say that one of DSM-5 negative consequences is going to be that, due to the decrease of the thresholds of many diagnoses, resources to treat seriously ill patients, which are already poor, will be even more so because they will be redirected for the multitude of slight 'patients', who will be damaged by the new diagnoses they will be labeled with" (Migone, 2013).

360 If on one hand the pathologic sphere gets larger and larger, on the other the weakest people concerned bear the brunt of it and have to deal with troubles of existence they do not know, which derive from financial models dictating what traits they have to give to their existence with no social support. Consumptions that have to be increased represent the real law of the market even in the field of health.

From a psychiatric and social viewpoint, the publication of DSM-5 will increase confusion, the border that separates normality and pathology will be even more ambiguous, giving birth to diagnoses with a questionable usefulness as far as its discriminating ability is concerned, which will only be favorable for the pharmaceutical industry. Once again the financial market will have the chance to lift its victory banner, over any ethical consideration, or simply good sense.

Among "scientific" confusion, increase of the individual weakness, media pressure, and rarefied devices, for people and entire communities orientation will become uncertain and disordered. Relying on "specialists," recognizing their skill 375 and discernment is a problem with respect to which users have serious troubles. Doctors often show lack of clarity. Due to their education, they tend to refer to a naturalistic-scientific model, which people do not fully understand and share. Users do not adapt themselves very well to be considered as a number of organs to treat and explore; they often see their requests compressed and inexpressible in relation to times and modalities of the model. These two aspects sometimes do not leave space for carefully listening to the patient's reasons and narration, not only the symptoms he/she shows. Once again involved, as they are, by the myth of performance, they neglect the human aspect, the patient's history and biography, and only worry about solving discomfort and illness by means of technology and prescriptions. $^{6}$

The same ethical, but mostly technical, considerations of medical diagnostics sketched by J. C. Weber that are fully included in the scientific paradigm and put it in crisis, must actually have to deal with one among many paradoxes of capitalism.

Hartmut Rosa (2011) says, "Life runs away. The acceleration given to our

390 life affects our ability to deeply understand the time we live in. [...] The basic reflection retreats and we can no more understand sense and consequences of our 
actions" (p. 387). So in professions, too, contact is lost both with what we do and people and their needs.

The critical point, the hardest problem, is understanding and revealing the weight of social and/or personal conditioning, the imposed, but not insurmountable, obligation connected to cultural duties.

Below are listed just some of them:

- Institutional pressures (roles, functions, obligations, and rules);

- The habitus (Bourdieu, 2000) (i.e., the tendency to reproduce stereotyped cultural forms);

- The financial compression we have already talked about;

- Finally, a not secondary aspect for psychological and social research and practice is connected to our anxiety for the method (Devereux, 2012), which causes forms of cognitive and emotional defense, especially as far as otherness is concerned.

For example, what margins of autonomy and freedom are today allowed to men and women who work in the social and have their relationships as a starting point?

How are knowledge transmission and professionals' training (especially psychologists and psychotherapists) carried out?

What epistemological equipment is given to them and with what awareness of the obligations it involves, limits first of all connected to ethical responsibility?

Speaking of recognition, committing to it with reflexive awareness, even with the aforementioned problems, offers the chance to become aware of the limits and possibilities of human and social sciences and especially committing to the perspectives of a more careful psychotherapy in line with the patients' needs, but also the possibilities the psychological intervention can promote in every field.

Regarding this, Paul Ricoeur's reflections (2005) can be useful for recognition and recovering some topics contained in the book edited by Alain Caille (2007), which open other interesting perspectives for a clinical treatment of discomfort.

Following this perspective, in his article, titled "Injustice et reconnaissance [Injustice and recognition]," Dubet (in Caillé, 2007) points out how "the denominator of a large number of injustices and sufferings has to be referred to one's Self and identity" (p.).

Forms of injustice, disdain, racism, and sexism have always existed in all societies and times, and form a certain viewpoint, they have weakened themselves just in our hypermodern societies. Something, however, has radically changed with respect to the past. Today, each individual perceives more the attack to his or her integrity and identity, and feels that the existence of those groups he/she tries to belong to is threatened. The common feeling is that you are not influential in decisions and decisive changes but instead subject not only to "normal" restrictions imposed by society, but also a suffocating, oversized control that makes us powerless when dealing with indefinite forces often called with different names but that allow no identification: system, financial structure, hidden powers, and so on. What everybody claims for himself and the groups he belongs to is a larger and more continuous recognition than what the social and relational reality can allow. 
He also claims the chance to be more present and trenchant in determining his own existence, as well as the choices mostly connected to consumptions. Being that there no possibility to act and contribute to one's own and the society's development, the consequence is a continuous, at times confused, request, connected to a persistent dissatisfaction and endless re-launching challenges. It is on the level of feelings and emotions, besides the larger one of social justice, that the angriest quarrels take place. More precisely, the recognition takes place in the intersection among individual lived experiences, social justice and representation of one's self, society, and group. Dubet (2007) says: "When individuals try to make their merits recognized, everyone becomes the other people's competitor and social cohesion, trust and 'natural' order are threatened" (p.). We witness a struggle involving the single individual and/or his group against all the others to claim his right to be recognized. Due to his nature, the competitors' recognition is not likely to happen, while the challenge is taking place. The struggle for recognition is therefore 450 an eternal test, as if recognizing in its double reflexive and rational meaning was a rare issue the value of which is connected to its scarcity. This conception of uncommon resource to be divided and not shared makes recognition something triggering the conflict rather than helping weaken them. Recognition, connected to social injustice and the absence of a qualified authority one can identify with, created discomfort.

Another word, being as usual as it is undefined, has thus acquired a weighty value, that of "merit." As a matter of fact, today, rather than a generic and interpersonal recognition, valid for those unalienable characteristics, everyone bears with him- or herself, it is the merit we receive or give ourselves that mostly arouses nightmarish thoughts.

We give an indefinite and generic authority, which we often call society and identify from time to time with our office manager, or employer, the commitment of a favorable sentence, while sometimes, what Honneth (2007) calls "preliminary recognition" remains overshadowed.

465 As I have previously mentioned, taking on the other person's perspective needs a preliminary form of recognition. The autonomy achieved from the caregiver later becomes autonomy from everybody. It is an autonomy that requires respect and recognition of one's own value, but also, mutually, the other person's respect and recognition. Social life can only rest on the value everybody gives to him- or herself and other people, too (Judge, Tibaldi, 1994).

The value given today to human resources, which is considered as "merit" is essentially based on a temporary, contingent, measurable recognition that can be overused, thus basically subject to oscillations and reconsiderations. In this sense, value becomes a synonym of merit. Human resources are today no more considered for their intrinsic value, but on the basis of the usefulness they can have at a given moment and for a given task, therefore for their exchange value.

People become an exchange value, sometimes considered resources, sometimes redundancy, in any case subject to a constant assessment of their performance and usefulness. Just like any other product (consider the importance given to training, requalification, etc.), they undergo a quick decline. An elderly worker is a waste, 
costs too much, and cannot be adapted; the cost/benefit ratio considers more the aspect connected to costs.

Today, each product is desirable, fashionable, and can only stay on the market for a short period. Its obsolescence can be measured in a one year, or even shorter, time span, mostly if it has to do with high technology. This does not depend on its functionality, that is, the fact of being able to carry out the task it has been planned for, but for marketing and competition reasons. In order to stay on the market, it is necessary to keep on renovating, adding new performances and technologies at an always faster rhythm. So as it is for products, the same happens for human beings.

Value is measured in a given moment, work performance has a functional weigh, linked to a determined time, and is measured through the market and its requests.

\section{FINAL REFLECTIONS}

Conclusions concerning a rich and extremely important theme can only be partial. In any case the theme of recognition, which today has always greater space and relevance, deserves further attention. I have sketched here only some aspects and problems connected to this theme. I think many others still have to be carefully studied.

Here are just some among the most urgent:

- The dynamics between recognition and gift, developed by Ricoeur (2005), Marcel Mauss (1950/2000), and the M.A.U.S.S. (Mouvement Anti-Utilitariste dans les Sciences Sociales [Anti-Utilitarian Movement in the Social Sciences]). Recognition must be considered as a non-utilitarian, nonseductive exchange, but as basis of interpersonal relationships that create well-being and growth.

- That between recognition and empathy, mostly for the developments of clinical psychotherapy. Not only because it represents a mature re-release of preliminary recognition, source of all possible autonomy processes, but also because it triggers the real engine for change.

- That of recognition in the group and mostly among groups.

The relationship between individual and group is fundamental and problematic, especially in our times, which do not only highlights individual performances and see the others and the group as a dreaded and desired place. Norbert Elias had already dealt with this problem, and, following his influence, Foulkes and Bion developed theses that could articulate the relationship between individual and group. Moreover, Lavie (2008) refers to the contradiction in the modern world between personal achievements and social influences and conditioning, between Foulkes's attention for the individual in the group and Bion's focus on the psychotic or work group on the individual.

There is also the problem concerning either individual or collective action feasibility. In other words, we need to understand to what extent today the individual can find the ability to act and not only be part of a series of exploited goods in his or her social fragmentation and dislocation. What we are facing today is the power 
expressed by masses (migrants, political-religious fundamentalism, refugees, etc.) the individual seems not be able to fight against with suitable defenses unless closing and rejecting it.

Human and social relationships are the only means to come back to and show the ability to act. In particular, recognition can also be seen as moral acting possibility. Financial neocapitalism imposes as a fundamental rule, in order to be recog530 nized, the ability to be flexible both to acquire a financial and consumption-related possibility, and be visible. In this perspective, the individual is considered not for his human and relational characteristics, but as a consumer who acquires value for their consumption action; as soon as it stops, for various reasons, he or she becomes invisible.

535 Honneth and Hartmann (2010) are finally the authors who sketch the "paradoxical" drift of today's capitalism, considering the evolution that has been taking place from the 1980s until present days. From the "social democratic" era (which in Italy corresponds to governments with a Christian Democratic majority), to present neoliberal capitalism, which develops around a "crystallization of 540 the recognition model."

The social democratic model has allowed long-lasting, stable, and protected careers, which have given the individuals the chance to assign to their existence a wide perspective and horizon. Thinking that everyone's life could have a constantly progressing civilization-related and material development was probably an

545 illusion. However, in the social democratic period, the people's project addressed the whole existence and also looked at following generations. Neoliberal capitalism has broken all this, characterizing itself on the contrary with working careers linked to individualized projects controlled by widespread performance assessment models. In this case-the authors say- the worker has changed into "a

550 labor-force-entrepreneur, or entrepreneur of himself, who does not participate to capitalistic practices under the pressure of external constrictions or stimuli any more, but, so to say, thanks to the strength of his autonomous motivation to performance."

The consequences of such a change have produced in individual conducts a pronounced individualism and the dispersion of solidarity.

Not only this, the request for an always creative performance, an instability in everyone's existential paths, with the impossibility to build and maintain longlasting connections, so as the troubled conquest of a stable and permanent job, has given birth to intense anxieties and depressive feelings. It has produced an always

560 higher and more unstable request of competences and a cancellation of the border between private and professional and social sphere.

A characteristic of contract work is that, when it has been carried out, it passes into the sphere of oblivion. There is another project, often very different from the previous one, which cannot take into account collected experience, which 565 requires new competences and determines its value and effectiveness in the present moment. A single individual's career is so fragmented that the person is not considered as far as their entire professional experience is concerned, but for what he/she is able to produce and carry out in a given moment. The following project is something new that requires new competences and inventive abilities, as well 
as a great reconversion and adaptation ability. The person's value is no more considered in the long term of their career, where they can assert their experience, as well as the professional improvement and emotional stability they have achieved. The heritage and resources acquired in a long period going from apprenticeship to the last activities lose their validity. In this case, the only assessment purpose is the operating instant, for which intuitive readiness, creativity, and flexibility are required.

In this continuous metamorphosis, the feelings of stability, unitarity, and progression are obviously lacking, and building every time the meaning of one's own existence, both from a professional and a personal viewpoint, becomes a painful operation.

Q32 In this reality, "the trouble of being ourselves" (Ehremberg, 1999) is also connected to the feeling of being responsible for such a condition, with no other viable option, and not being able to grasp the opportunities that had shown. Of course there is an interconnection between social and financial dynamics and individual troubles. In a demanding and sparkling world, not being able to achieve the goals we wish to get to can cause an inadequate self-assessment.

And yet, what are the reference points that allow an understanding of what is our collocation, the space suitable for us, if we are led to do and have always more, and reach always higher goals?

Answers cannot be left to the single person's initiative.

We need instead to find or get back to forms of reciprocal recognition, recreate processes of dis-identification with respect to individual and collective constrictions, learn to build alternative and creative subjectification processes, the initiative of which comes from single individuals and groups as well, which seems a practicable way, especially when the engine of competition, its real usefulness, appears as worn-out and with no perspective.

\section{NOTE}

1. "We are now living in an individualism characterized not by personalization, but a collapse of connections, an individualism become destructor of collective sense of belonging and therefore of everyone's personal grounds" (Ehremberg, 2010).

2. I would like to point out that for women, too, and not only those who live in the Western world, being recognized has always been representing a crucial problem in their lives, as Cantarella (2012) reports.

3. This is what Kaës (2013) says: "Ce qui fait le malêtre ordinaire, c'est l'effacement progressif du sujet, l'absence de répondant à nos question sur ce que nous sommes et devenons, la disparition du répondant humain aux demandes que nous formulons à des appareils administratifs, les microtraumas de la vie quotidienne que les rêves ne réparent plus et que les fictions des médias ne font qu'endormir, ce sont les grands traumatismes qui ont troué l'histoire, les liens entre les générations, la confiance dans l'humanité" (p. 5).

4. We would like to mention here just a couple of interesting works from a philosophical viewpoint as well as a text addressed to psychologists that has been recently published:

- Benan, E., \& Vigna, C. (Eds.). (2004). Etica Plurale: giustizia, riconoscimento, responsabilità. [Plural ethics, justice, recognition, responsibility] Milan: Vita e Pensiero.

Q34 - Vaccaro, S. (2002). Afterword. In A. Honneth, Critica del Potere. La teoria della società in Adorno, Foucault e Habermas. [Critique of power. The theory of society in Adorno, Foucault and Habermas]. Bari ed. Dedalo. 
- Molinari, E., \& Cavaleri, P. A. (2015). Il dono in tempo di crisi. Per una psicologia in tempo di crisi. [The gift in times of crisis. For a psychology in times of crisis]. Milan: Raffaello Cortina.

5. Amerio (2006) represents an exception, since he highlights, in Honneth, the passage from politics to morals, theme we will come back to later on.

6. J. C. Weber (Typed) says that "Beaucoup d'études de terrain ont montré comment l'éthos du malade orateur influence le diagnostic du médecin : une présentation soignée, un vocabulaire clair, des marques de politesse, une docilité affichée, mettent le médecin en confiance. Certains patients par contre, identifiés sous des types disqualifiés (manipulateurs, exigeants, simulateurs, séniles, alcooliques, drogués ou psychopathes) suscitent assez systématiquement des mécanismes de défense qui altèrent sérieusement les compétences diagnostiques et l'engagement thérapeutique de leur médecin."

\section{REFERENCES}

Arendt, H. (2003). La banalità del male_Eichmann a Gerusalemme. Milan, Italy: Feltrinelli. (Original work published 1963)

630 Bourdieu, P. (2000). Esquisse d'une théorie de la pratique. Paris, France: Éditions du Seuil. Caillé, A. (Ed.). (2007). La quête de reconnaissance. Nouveau phénomène social total.

Paris, France: Éditions la Découverte.

Cantarella, G. (2012). Donne nei gruppi terapeutici. Milan, Italy: Franco Angeli.

Dejours, C. (2009). Souffrance en France (2nd ed.). Paris, France: Éditions du Seuil.

635 Devereux, G. (2012). De l'angoisse à la méthode dans les sciences du comportement. Paris, France: Flammarion.

Dubet, F. (2007). Injustice et reconnaissance, in A. Caille cit.Paris, France: Éditions la Découverte.

Ehremberg, A. (1999). La fatica di essere se stessi. Torino, Italy: Einaudi.

640 Ehremberg, A. (2010). La società del disagio. Torino, Italy: Einaudi.

Foucault, M. (2014). Considerazioni sul marxismo, la fenomenologia e il potere. In Conversazione con C. Gordon e P. Patton, Micromega 2. (Original work published 1978)

Habermas, J., \& Taylor, C. (2002). Multiculturalismo. Lotte per il riconoscimento. Milan, Italy: Feltrinelli (Original work published 1996)

645 Honneth, A. (2000). La lutte pour la reconnaissance [The struggle for recognition]. Paris, France: Folio Gallimard.

Honneth, A. (2006). La société du mépris. Paris, France: La Découverte Poche.

Honneth, A. (2007). La Réification. Paris, France: Gallimard.

Honneth, A. (2013). Un monde de déchirements. Pari, France: La Découverte.

650 Honneth, A., \& Hartmann, M. (2010). Paradossi del capitalismo. Un programma di ricerca. In A. Honneth (Ed.), Capitalismo e riconoscimento. Florence, Italy: University Press.

Kaës, R. (2013). Malêtre. Paris, France: Dounod.

Lavie, J. (2008). "Uomo aperto", Homo clausus e il quinto assunto di base: Concetto ponte tra tradizione bioniana e tradizione foulkesiana. Funzione Gamma no. 19.

Mauss, M. (2000). Saggio sul dono, in Teoria generale della magia. Torino, Italy: Einaudi. (Original work published 1950)

Migone, P. (2013). Aspettando il DSM 5. Il Ruolo terapeutico n. 122. Milan, Italy: Franco Angeli.

Ricoeur, P. (2005). Percorsi del riconoscimento. Milan, Italy: Raffaello Cortina.

660 Rosa, H. (2011). Accélération. Une critique sociale du temps. Paris, France: La Découverte. Taylor, C. (2009). L'età secolare. Milan, Italy: Feltrinelli. 